\title{
Sea otter mortality in fish and shellfish traps: estimating potential impacts and exploring possible solutions
}

\author{
Brian B. Hatfield ${ }^{1, *}$, Jack A. Ames ${ }^{2}$, James A. Estes ${ }^{3}$, M. Tim Tinker ${ }^{4}$, \\ Andrew B. Johnson ${ }^{5}$, Michelle M. Staedler ${ }^{5}$, Michael D. Harris ${ }^{6}$ \\ ${ }^{1}$ US Geological Survey, Western Ecological Research Center, Piedras Blancas Office, PO Box 70, San Simeon, \\ California 93452, USA \\ ${ }^{2}$ Marine Wildlife Veterinary Care and Research Center, California Department of Fish and Game, 1451 Shaffer Road, \\ Santa Cruz, California 95060, USA \\ ${ }^{3}$ Department of Ecology and Evolutionary Biology, University of California, Center for Ocean Health, 100 Shaffer Road, \\ Santa Cruz, California 95060, USA \\ ${ }^{4}$ US Geological Survey, Western Ecological Research Center, Long Marine Laboratory, 100 Shaffer Road, Santa Cruz, \\ California 95060, USA \\ ${ }^{5}$ Sea Otter Research and Conservation, Monterey Bay Aquarium, 886 Cannery Row, Monterey, California 93940, USA \\ ${ }^{6}$ California Department of Fish and Game, OSPR-Veterinary Services, 1385 Main Street, Morro Bay, California 93442, USA
}

\begin{abstract}
Sea otters Enhydra lutris can be bycaught and drowned in fishing pots and traps, which may pose a threat to the welfare of otter populations. We explored this potential problem and its solutions using a wide variety of analyses. We exposed live California (USA) sea otters to finfish traps, lobster traps, and mock Dungeness crab traps in captive trials and found that the animals attempted to enter the circular and rectangular fyke openings, with some becoming entrapped. Using both live and dead sea otters, we found that a $3 \times 9$ inch $(7.6 \times 22.9 \mathrm{~cm})$ fyke opening $(1$ inch narrower than the $4 \times 9$ inch [10.2 $\times 22.9 \mathrm{~cm}$ ] openings currently used in California's commercial Dungeness crab fishery) would exclude most free-living (i.e. weaned from their mothers) otters while permitting the undiminished capture of crabs. Observer programs do not currently exist in California for these fisheries, so we calculated the effort required by an observer program to document sea otter bycatch over a range of hypothetical levels and evaluated the impact of those mortality rates on population growth. These analyses demonstrate that significant mortality from bycatch might easily go undetected, even with seemingly high levels of observer effort. As sea otters reoccupy portions of their former habitat in California, co-occurrence with finfish and shellfish traps with relatively large fyke openings will increase.
\end{abstract}

KEY WORDS: Sea otter $\cdot$ Enhydra lutris $\cdot$ Bycatch mortality $\cdot$ Shellfish traps $\cdot$ Fish traps

\section{INTRODUCTION}

Bycatch of marine mammals, birds, turtles, and other species is a worldwide conservation and management issue (Alverson et al. 1994, Hall 1996, Crowder et al. 2008). Numerous populations of marine vertebrates, including many marine mammals, have been reduced via entrapment and entanglement in various types of fishing gear, substantially in some cases (Melvin \& Parrish 2001, Lewison et al. 2004, Read et al. 2006). Even localized small-scale fisheries can result in unsustainable levels of bycatch (Peckham et al. 2007, Campbell et al. 2008). However, in many cases there is no reliable method to quantify bycatch, to estimate its effect on the demography of affected species (Poole et al. 2007, Slooten 2007, Moore \& Read 2008, Zydelis et al. 
2009), or even to determine when and where it is occurring (Veran et al. 2007). In such cases, it therefore may be necessary to rely on indirect evidence and simulation analyses to estimate population-level impacts of bycatch (Arnold et al. 2006, Slooten 2007, Veran et al. 2007, Moore \& Read 2008).

The California sea otter Enhydra lutris nereis population was designated as threatened under the US Endangered Species Act because of its relatively small size and geographic range; its failure to recover from depletion due to the Pacific maritime fur trade despite large expanses of unoccupied and suitable habitat at both ends of its current range (Kenyon 1969, Tinker et al. 2006, 2008a, US Geological Survey, USGS unpubl. data); and various known or perceived threats from increased human activities in coastal California (Ralls et al. 1996). The lack of recovery in this population is especially notable because rapid population growth and recovery have occurred elsewhere within the sea otter's historical range (Kenyon 1969, Estes et al. 1989, Estes 1990). In recent years, studies have focused largely on pollution, disease, and other health-related factors as potential explanations for the California sea otter's lack of recovery (Jessup et al. 2007). And while several disease processes have proven to be common sources of mortality (Thomas \& Cole 1996, Miller et al. 2002, Kreuder et al. 2003, Thomas et al. 2007), a proper understanding of the dynamics of this population is lacking. Elevated mortality is clearly responsible for the lack of recovery. Yet only about half of the estimated deaths are recovered as stranded carcasses, and these cannot be assumed to represent overall mortality (Estes et al. 2003, Gerber et al. 2004). Relying upon recovered beach-cast carcasses to infer trends in mortality patterns requires caution (Hart et al. 2006). Sea otters that die in fishing gear exemplify this problem: All sea otters that drowned in bottom set nets in the 1980s in central California immediately sank when discarded into the ocean and had a low probability of later recovery on the beach (Wendell et al. 1986 and present study).

Bycatch mortality of California sea otters caused a population decline from the mid-1970s through the early 1980s (Estes et al. 2003). Although this source of mortality was identified and mitigated (Wendell et al. 1986), other fisheries have since expanded or developed that could affect the California sea otter population. Of particular concern is the potential influence of incidental losses in fish and shellfish traps, as there have been many documented cases of sea otters drowning in various kinds of gear (Table 1; Fig. S1 in the supplement at www.int-res.com/articles/suppl/ n013p219_supp.pdf). Although direct evidence for anything but occasional bycatch in present-day fisheries is lacking, patterns of association are suggestive.
For instance, the translocated sea otter population at San Nicolas Island - an area with an intensive lobster Panuliris interruptus fishery - has failed to increase as rapidly as expected (Hatfield 2005), despite abundant food and the excellent health and body condition of the otters (Tinker et al. 2008b). California sea otters also overlap with a large Dungeness crab Cancer magister fishery at the northern end of the otters' range. On one reconnaissance flight over northern Monterey Bay, in 2004, approximately 200 pot buoys were observed in the immediate vicinity of $>20$ sea otters (J. A. Ames, M. M. Staedler, M. D. Harris pers. obs.). Similarly, threats will potentially grow as California sea otters expand their range to the south, where they will encounter increasing numbers of lobster and finfish traps with unregulated sizes of fyke openings.

The southern sea otter exemplifies a conservation challenge facing many endangered marine mammal species: the potential for bycatch to impede recovery, while the ability to measure bycatch directly is difficult or impossible. In the present study we have attempted to better understand the issues in a multifaceted manner by: summarizing previous records of bycatch; evaluating the results of an experiment with dead sea otters to determine the probability of their recovery; measuring and experimenting with living and dead sea otters to determine the sizes of fyke openings through which sea otters can pass; experimenting with live captive sea otters to determine their behavioral tendencies to enter various traps and pots; experimenting with live Dungeness crabs to determine the sizes of fyke openings through which crabs of different sizes can pass; fishing with experimental crab pots with different-sized fyke openings to determine the extent to which various reductions in the opening size might affect the crab size and catch rate; and determining the observer effort required within the Dungeness crab fishery to document sea otter bycatch.

\section{MATERIALS AND METHODS}

Probability of recovering drowned sea otters. Between October 1982 and August 1985, 35 drowned sea otters were recovered from bottom-set tangle nets in the California halibut set-net fishery (Wendell et al. 1986). We re-analyzed the raw data from Wendell et al. (1986) to determine the probability of drowned otters being recovered later as beach-cast carcasses. Twentyfive of the drowned sea otters were observed closely enough to determine whether they sank or floated when released back into the ocean after removal from the nets. Of these 25, 13 were marked with a cattle ear tag affixed to a nylon line secured tightly around the thorax immediately behind the forelimbs for identifica- 
Table 1. Enhydra lutris. Twenty-one reported instances of sea otters taken in trap gear. F: female, M: male, nd: no data, NMFS: National Marine Fisheries Service

\begin{tabular}{|c|c|c|c|c|c|c|c|c|c|}
\hline Date & Location & Trap type & $\begin{array}{l}\text { Shape of } \\
\text { opening }\end{array}$ & $\begin{array}{c}\text { Size of } \\
\text { opening }(\mathrm{cm})\end{array}$ & $\begin{array}{l}\text { Depth } \\
(\mathrm{m})\end{array}$ & Sex & $\begin{array}{l}\text { Length } \\
(\mathrm{cm})\end{array}$ & $\begin{array}{l}\text { Weight } \\
(\mathrm{kg})\end{array}$ & Comments \\
\hline Aug 74 & $\begin{array}{l}105 \mathrm{~km} \text { off Cape } \\
\text { Mordvinof, AK }\end{array}$ & Crab & nd & nd & 80.5 & $\mathrm{~F}$ & 103 & 30 & $\begin{array}{l}\text { Reported size is small for an adult } \\
\text { female (Newby 1975) }\end{array}$ \\
\hline 1982 & Alaska & Crab & nd & nd & $\begin{array}{l}47.5- \\
58.5\end{array}$ & nd & nd & nd & $\begin{array}{l}\text { Fishery interaction questionnaire } \\
\text { (T. Simon-Jackson unpubl. US } \\
\text { Fish and Wildlife Service report) }\end{array}$ \\
\hline 1983 & Alaska & Crab & nd & nd & nd & nd & nd & nd & $\begin{array}{l}\text { Fishery interaction questionnaire } \\
\text { (T. Simon-Jackson unpubl.) }\end{array}$ \\
\hline Nov 87 & $\begin{array}{l}\text { Santa Cruz } \\
\text { Is., CA }\end{array}$ & Lobster & & & nd & M & nd & 27 & $\begin{array}{l}\text { Tagged animal, reported by } \\
\text { fisherman }\end{array}$ \\
\hline Dec 87 & $\begin{array}{l}\text { Monterey } \\
\text { Harbor, CA }\end{array}$ & $\begin{array}{l}\text { Black } \\
\text { cod? }\end{array}$ & Circular & 25.4 (diam.) & nd & $\mathrm{F}$ & 123 & 49.1 & $\begin{array}{l}\text { Bloated carcasses floated trap to } \\
\text { surface }\end{array}$ \\
\hline Dec 87 & $\begin{array}{l}\text { Monterey } \\
\text { Harbor, CA }\end{array}$ & $\begin{array}{l}\text { Black } \\
\text { cod? }\end{array}$ & Circular & 25.4 (diam.) & nd & M & 89 & 20.1 & Trapped with mother \\
\hline $1991(?)$ & $\begin{array}{l}0.8 \mathrm{~km} \text { off Pt. } \\
\text { Santa Cruz, CA }\end{array}$ & $\begin{array}{l}\text { Rock } \\
\text { crab }\end{array}$ & & & $\begin{array}{l}9.1- \\
18.3\end{array}$ & nd & nd & nd & $\begin{array}{l}\text { Subadult, skeleton, recovered in } \\
\text { June } 1992\end{array}$ \\
\hline 1991 & $\begin{array}{l}\text { Within } 8 \mathrm{~km} \text { of } \\
\text { Attu Island, AK }\end{array}$ & $\begin{array}{c}\text { Pacific } \\
\operatorname{cod}^{\mathrm{a}}\end{array}$ & Rectangular & $15 \times 21.5^{\mathrm{b}}$ & nd & nd & nd & nd & $\begin{array}{l}\text { Trap lost 1991, recovered } 1992 \text { with } \\
\text { skull (NMFS Observer Program) }\end{array}$ \\
\hline May 92 & $\begin{array}{l}\text { Within } 8 \mathrm{~km} \text { of } \\
\text { Attu Island, AK }\end{array}$ & $\begin{array}{l}\text { Pacific } \\
\operatorname{cod}^{\mathrm{a}}\end{array}$ & Rectangular & $15 \times 21.5^{\mathrm{b}}$ & 45.7 & nd & 125 & nd & $\begin{array}{l}\text { Curvilinear length (NMFS } \\
\text { Observer Program, Perez 2003) }\end{array}$ \\
\hline May 92 & $\begin{array}{l}\text { Within } 8 \mathrm{~km} \text { of } \\
\text { Attu Island, AK }\end{array}$ & $\begin{array}{c}\text { Pacific } \\
\operatorname{cod}^{\mathrm{a}}\end{array}$ & Rectangular & $15 \times 21.5^{b}$ & 73.2 & nd & 120 & nd & $\begin{array}{l}\text { Curvilinear length (NMFS } \\
\text { Observer Program, Perez 2003) }\end{array}$ \\
\hline May 92 & $\begin{array}{l}\text { Within } 8 \mathrm{~km} \text { of } \\
\text { Attu Island, AK }\end{array}$ & $\begin{array}{l}\text { Pacific } \\
\operatorname{cod}^{\mathrm{a}}\end{array}$ & Rectangular & $15 \times 21.5^{b}$ & 69.5 & nd & 64 & nd & $\begin{array}{l}\text { Curvilinear length is certainly in } \\
\text { error (NMFS Observer Program, } \\
\text { Perez 2003) }\end{array}$ \\
\hline Jun 92 & $\begin{array}{l}\text { Within } 8 \mathrm{~km} \text { of } \\
\text { Attu Island, AK }\end{array}$ & $\begin{array}{l}\text { Pacific } \\
\operatorname{cod}^{\mathrm{a}}\end{array}$ & Rectangular & $15 \times 21.5^{\mathrm{b}}$ & 43.9 & nd & 95 & nd & $\begin{array}{l}\text { Standard length (NMFS } \\
\text { Observer Program, Perez 2003) }\end{array}$ \\
\hline Jul 92 & $\begin{array}{l}\text { Within } 8 \mathrm{~km} \text { of } \\
\text { Attu Island, AK }\end{array}$ & $\begin{array}{c}\text { Pacific } \\
\operatorname{cod}^{\mathrm{a}}\end{array}$ & Rectangular & $15 \times 21.5^{b}$ & 45.7 & nd & nd & nd & $\begin{array}{l}\text { NMFS Observer Program and } \\
\text { Perez (2003) }\end{array}$ \\
\hline Jul 92 & $\begin{array}{l}\text { Within } 8 \mathrm{~km} \text { of } \\
\text { Attu Island, AK }\end{array}$ & $\begin{array}{l}\text { Pacific } \\
\operatorname{cod}^{\mathrm{a}}\end{array}$ & Rectangular & $15 \times 21.5^{b}$ & 51.2 & nd & nd & nd & $\begin{array}{l}\text { NMFS Observer Program and } \\
\text { Perez (2003) }\end{array}$ \\
\hline Jul 92 & $\begin{array}{l}\text { Within } 8 \mathrm{~km} \text { of } \\
\text { Attu Island, AK }\end{array}$ & $\begin{array}{l}\text { Pacific } \\
\operatorname{cod}^{a}\end{array}$ & Rectangular & $15 \times 21.5^{\mathrm{b}}$ & 60.4 & nd & nd & nd & $\begin{array}{l}\text { NMFS Observer Program and } \\
\text { Perez (2003) }\end{array}$ \\
\hline Aug 92 & $\begin{array}{l}\text { Within } 8 \mathrm{~km} \text { of } \\
\text { Attu Island, AK }\end{array}$ & $\begin{array}{c}\text { Pacific } \\
\operatorname{cod}^{\mathrm{a}}\end{array}$ & Rectangular & $15 \times 21.5^{b}$ & nd & nd & nd & nd & $\begin{array}{l}\text { NMFS Observer Program and } \\
\text { Perez (2003) }\end{array}$ \\
\hline $\begin{array}{l}\text { Jun- } \\
\text { Aug } 92\end{array}$ & \multicolumn{3}{|c|}{$\begin{array}{l}4 \text { otters taken in same area in same gear } \\
\text { by same vessels }\end{array}$} & nd & nd & nd & nd & nd & $\begin{array}{l}\text { Reported by fishers to (but not seen } \\
\text { by) on-board NMFS observers } \\
\text { (NMFS Observer Program) }\end{array}$ \\
\hline Jul 07 & $\begin{array}{l}0.4 \mathrm{~km} \text { north } \\
\text { of Craig, AK }\end{array}$ & $\begin{array}{l}\text { Dungeness } \\
\text { crab }\end{array}$ & nd & nd & nd & M & nd & nd & Reported by sea otter hunter \\
\hline
\end{tabular}

tion later if recovered on the beach. We measured the proportion of these tagged animals that were recovered through the existing stranded sea otter program and plotted the fate of each carcass $(1=$ recovered on beach, 0 = never recovered) against the water depth at the site of release. A logit function was fit to these data.

Exposing captive sea otters to finfish and lobster traps. We exposed 9 sea otters at the Monterey Bay Aquarium in individual trials to a baited fish trap placed in a circular, $4.0 \mathrm{~m}$ diameter holding tank filled with seawater to a depth of $1.2 \mathrm{~m}$. The trap, which was commer- cially made, had 2 funnel-shaped openings (= fykes) with inner openings that measured 5.5 inches $(14.0 \mathrm{~cm})$ in diameter - a common size for traps used in the central California live-fish fishery. The trap was baited with approximately $1 \mathrm{lb}(0.45 \mathrm{~kg})$ of squid (common bait used in the live-fish fishery) and 2 or 3 live crabs of the genus Cancer (frequently caught incidentally in fish traps). We also exposed 2 otters to a similarly baited, commercially purchased, 2-chambered lobster trap with circular fyke openings. The outer and inner chamber openings were 6.0 inches $(15.2 \mathrm{~cm})$ and 5.5 inches $(14.0 \mathrm{~cm})$ in diameter, 
respectively. The trials were observed remotely using a video monitor. None of the tested sea otters sustained injuries during the experiments.

Size of opening through which sea otters can transit. Studies with sea otter carcasses: Using dead sea otters that were collected by the California sea otter stranding network, we pulled carcasses of various ages and sizes through progressively smaller (by 0.25 inch [0.6 cm] diameter increments from 7.5 inches [19.1 cm] to 3.0 inches $[7.6 \mathrm{~cm}]$ ) rigid rings, and through progressively narrower (by 0.25 inch $[0.6 \mathrm{~cm}]$ height increments from 8.0 inches $[20.3 \mathrm{~cm}]$ to 2.0 inches $[5.1 \mathrm{~cm}]$; all were 9.0 inches [22.9 cm] wide) rigid parallel bars (Fig. S2 in the supplement at www.int-res.com/articles/suppl/n013p219_supp.pdf). We first measured the total length ( $\mathrm{cm}$ from snout to tail, lying face-up on a flat surface) of each sea otter carcass as an index of age (Laidre et al. 2006). Because mass measurements from carcasses are often unreliable (specimens vary greatly in body condition at death), we estimated live-body mass from body length derived from 344 live-captured, anesthetized, sea otters in California (USGS unpubl. data). We determined the minimum ring diameter and distance between bars that allowed passage for each carcass. We then fit a linear, least-squares regression to these data, in order to describe the functional relationship between sea otter size (length or mass) and the minimum trap opening size that an otter could transit.

Results from this experiment, which indicated that juvenile and some adult sea otters could enter typical traps used in the Dungeness crab, spiny lobster, and live finfish fisheries, prompted us to conduct 2 additional experiments, one to determine the size of rectangular openings that live, captive otters of different sizes would transit voluntarily and the other to make the same determinations for live Dungeness crabs of different sizes.

Studies with live sea otters: We exposed each of 7 captive sea otters to a variety of rectangular fyke-like openings. The openings were all 9 inches $(22.9 \mathrm{~cm})$ wide (the width in most Dungeness crab traps) but varied in height from 2.25 to 6.0 inches $(5.7$ to $15.2 \mathrm{~cm}$ ) in 0.25 inch $(0.6 \mathrm{~cm})$ increments (Fig. $\mathrm{S} 3$ in the supplement at www.int-res.com/articles/suppl/n013p219_ supp.pdf). We first measured the mass of each sea otter to use as an index of size and age. (Accurate length measurements are difficult to obtain from sea otters that are not anesthetized.) We then placed each animal inside a cage with a rectangular opening of progressively smaller size and waited to see whether it escaped through the opening. Some of the captive otters preferred to be inside the cage, so these individuals were placed outside and encouraged to enter by stocking the cage with food. We conducted these trials with the cages on land, or in only several inches of water, to eliminate any chance of drowning. Each otter was tested to a point where the handlers were confident that they had transited the narrowest possible opening. One young otter was re-tested after approximately 1 mo of growth, and we used this result as an independent data point. As with the carcass data, we fit a linear, least-squares regression to these data to describe the functional relationship between sea otter mass and the minimum trap opening size that the otters voluntarily transited.

Size of opening through which Dungeness crabs can transit. Captive experiments: At the California Department of Fish and Game (CDFG) laboratory in Santa Cruz, we constructed a $2.2 \mathrm{~m}$ long by $1.1 \mathrm{~m}$ wide by $0.5 \mathrm{~m}$ deep tank with running seawater. We then installed half of a commercial Dungeness crab trap at the center of the tank, thus dividing it into two $1.1 \mathrm{~m}$ halves that were accessible only through the trap opening (Fig. S4 in the supplement at www.intres.com/articles/suppl/n013p219_supp.pdf). We conducted a series of $24 \mathrm{~h}$ tests, each with 11 Dungeness crabs of different sizes, placing them in the tank outside the trap and placing bait inside the trap. After determining that the crabs would willingly pass through the unaltered trap opening, we reduced the opening height from the standard 4.0 inches $(10.2 \mathrm{~cm})$ to 2.0 inches $(5.1 \mathrm{~cm})$ in 0.25 inch $(0.6 \mathrm{~cm})$ increments, with replicate trials conducted for all heights except 2.0 inches $(5.1 \mathrm{~cm})$, by clamping a movable bar across the top of the opening. The height of the entrance was checked at the beginning and end of each $24 \mathrm{~h}$ experiment. To analyze the data we first tallied the proportion of crabs that were excluded at different opening heights. For those opening heights that excluded some crabs but allowed others to pass, we used logistic regression to analyze the relationship between the probability of exclusion and crab carapace width.

Open-ocean trapping experiments: This experiment was designed to determine how reducing the sizes of the trap entrances would affect crab-catch statistics. Three different periods (seasons) of experimental crabbing were conducted: in spring 2004 (just prior to the end of the commercial season) and in fall 2004 and fall 2005 (just prior to the opening of the commercial season). This work was done under contract with a commercial fisher in Half Moon Bay, California, who provided the fishing vessel (FV) 'Barbara Faye', traps, bait, fuel, and crew. Trap fykes were all 9 inches $(22.9 \mathrm{~cm})$ wide and adjusted to 1 of 6 possible opening heights: 4.0 inches $(10.2 \mathrm{~cm}$, unmodified, standard commercial size), 3.5 inches $(8.9 \mathrm{~cm})$, and at decreasing 0.25 inch $(0.6 \mathrm{~cm})$ increments to 2.25 inches $(5.7 \mathrm{~cm})$. Initially, traps with 3.75 inch $(9.5 \mathrm{~cm})$ high entrances were also used, but these were discontinued 
because the modifying bar was difficult to install for this size opening. We used this 'bar-addition method' because such a system could be welded or otherwise fitted in place by commercial fishers, should a fykesize-modification management policy be implemented in the future.

To avoid any bias associated with the order in which traps were set or pulled, we arbitrarily shuffled the sequence of fyke-opening treatments along trap lines on each set. We set equal numbers of traps with each fyke-size opening on each day of fishing, although the data from any trap where the fyke-modifying bar appeared to have shifted during a set were excluded from analysis, thus creating slightly unbalanced sample sizes. We used 1-way ANOVA to test for effects of fyke-size opening on each of 2 dependent variables: catch-per-unit-effort (CPUE, measured as the mean number of crabs caught per trap) and mean crab size (carapace width, in $\mathrm{cm}$ ) per trap set. ANOVA tests were followed by the Lilliefors test for normality and Levene's test for homogeneity of variance, as well as graphical examination of the residuals, to evaluate statistical assumptions. We then conducted post hoc comparisons (using the Tukey-Kramer method) to test for differences in CPUE and/or mean crab size between 4.0 inch $(10.2 \mathrm{~cm})$ fyke openings (the control) and all other opening heights. All statistical analyses were conducted using the Statistics toolbox in MATLAB (MathWorks).

Estimating observer effort. To calculate the relative intensity of observation that would be required to detect sea otter trap mortality, we first required a measure of the total fishing effort within the sea otter's range. We estimated this value at 20000 to 25000 trap pulls annually, based on the number of boats fishing in each region and information provided by CDFG wardens on the approximate number of trips per boat, trap sets per trip, and trap soak times. In order to provide a conservative estimate, we used the lower value (n = 20000 annual trap pulls) for further calculations, and we assumed only 1 sea otter could be killed per trap set (i.e. we ignored the possibility of multiple otters caught in 1 trap, but see Table 1, and Fig. S1 in the supplement).

Our target for a monitoring program was to assure a high probability $(\geq 95 \%)$ of detecting trap deaths, given that it was occurring. Thus, if $X$ otters are bycaught in traps each year, we wished to know how many trap pulls must be observed to obtain a $95 \%$ or greater probability of detecting at least one of these. We assumed that otter mortality in traps was a rare event that occurred independently among sets that could thus be modeled as a Poisson process. Based on these assumptions, we estimated the likelihood of detecting at least one of $X$ mortalities as $1-P_{0}$, where
$P_{0}$ is the probability of detecting zero of $X$ mortalities and is given by:

$$
P_{0}=\mathrm{e}^{-m(X) / N}
$$

where $N$ is 20000 (the total annual number of pulls) and $m$ is the number of trap pulls observed. To solve for the number of trap pulls that must be observed, we adjusted $m$ so that $P_{0}=0.05$, which corresponds to a $95 \%$ probability of observing at least one of the $X$ mortalities. We conducted this analysis over a wide range of potential mortality levels $(X=1$ to 300 trap deaths $\mathrm{yr}^{-1}$ ), and for each value of $X$ we calculated both the required monitoring effort and the expected effect on the annual rate of population growth $(\lambda)$. To estimate the effect on $\lambda$, we employed the population model developed by Tinker et al. (2006). We first ran model projections of population growth for the 1993-2001 period, using the vital rate estimates provided by Tinker et al. (2006), and then repeated the simulation with the vital rates adjusted to represent the removal of trap-related mortality. To adjust vital rates, we assumed that trap-related mortality was distributed randomly across the population with respect to sex and location but was restricted to juvenile and subadult age classes (age < 4 yr). We consider these to be biologically reasonable yet statistically conservative assumptions: there is no a priori reason to expect a bias towards one sex or another, younger animals are smaller in size and thus would be more likely to be entrapped, and spreading mortality to adult age classes and/or concentrating mortality spatially would tend to result in greater impacts on population growth (Tinker et al. 2006). We then calculated the percent difference in $\lambda$ between the 2 simulations, and used the resulting number as an estimate of the effect of trap mortality on population growth. Simulation analyses were conducted using MATLAB programming software (MathWorks).

\section{RESULTS}

\section{Probability of recovering drowned sea otters}

All 25 freshly dead sea otters that were recovered from bottom set nets and returned to the water at the site of drowning sank immediately. Four (31\%) of the 13 tagged carcasses were later recovered on the shore (Table S1 in the supplement at www.int-res.com/articles/suppl/n013p219_supp.pdf). There was a negative relationship between the water depth into which a tagged carcass was released and its likelihood of later recovery, described by the logit function $\left(R^{2}=0.46\right.$; Fig. 1):

$$
P(\text { recovery })=\mathrm{e}^{10.9-0.65 \times \text { depth }} /\left(1+\mathrm{e}^{10.9-0.65 \times \text { depth }}\right)
$$




\section{Exposing captive sea otters to finfish and lobster traps}

Of the 9 sea otters exposed to the fish trap, 5 made multiple attempts to enter the trap (Table 2). Three of these otters managed to push through the fyke past

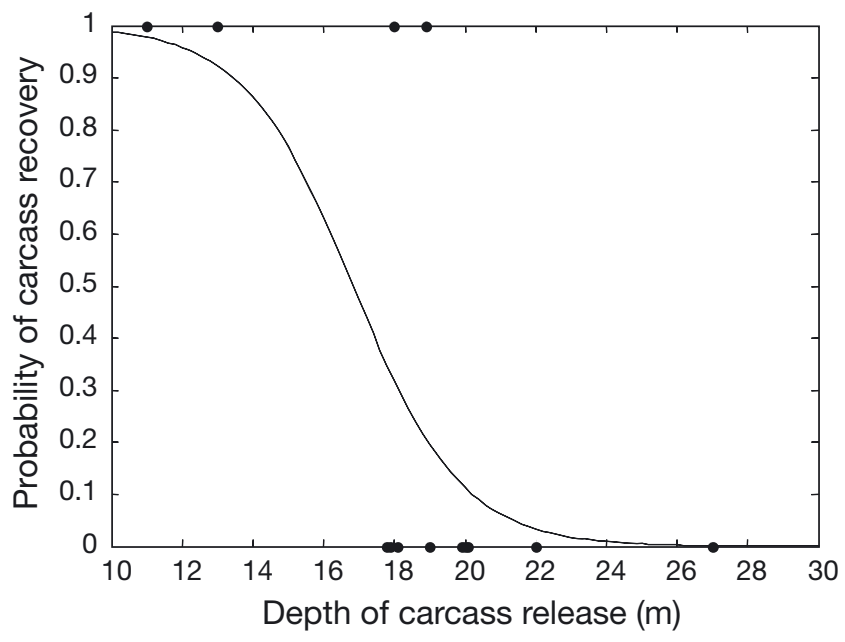

Fig. 1. Enhydra lutris. Probability that net-drowned sea otters placed in the ocean at different depths (m) will be recovered later as beach-cast carcasses. The experimental data points $(\bullet)$ indicate individual sea otter carcasses released at sea, while the smoothed probability curve was estimated by fitting a logit function to these data their forelimbs, but then pulled back out. Two of these otters bent the wire-framed fyke edge slightly outward toward the opening when they withdrew from the fyke opening. Another sea otter entered the trap completely on 3 occasions and apparently could not find her way out after 2 of the entries (she was subsequently brought to the surface and released unharmed).

Both sea otters exposed to the lobster trap attempted to enter it (Table 3). On 1 occasion, the smaller animal (weight: $10.9 \mathrm{~kg}$ ) transited the outer chamber completely, hardly slowing to pass through the 6 inch $(15.2 \mathrm{~cm})$ diameter openings.

\section{Size of opening through which sea otters can transit}

\section{Studies with dead sea otters}

Sixty-two dead sea otters were tested by pulling the carcasses through the smallest rigid rings and/or parallel bars possible (Table S2 in the supplement at www.int-res.com/articles/suppl/n013p219_supp.pdf). The minimum ring diameter was always larger than the minimum distance between the parallel bars because sea otters are not cylindrical in shape, but rather dorso-ventrally flattened. The average differ-

Table 2. Enhydra lutris. Experiment in which 9 sea otters were exposed to a commercial finfish trap in a controlled setting at the Monterey Bay Aquarium, California. Inner trap funnels had 5.5 inch $(14.0 \mathrm{~cm})$ diameter openings. F: female, M: male

\begin{tabular}{|c|c|c|c|c|c|c|c|c|c|c|}
\hline $\begin{array}{l}\text { Otter no. } \\
\text { (name) }\end{array}$ & $\begin{array}{l}\text { Date } \\
\text { tested }\end{array}$ & Sex & $\begin{array}{l}\text { Weight } \\
\text { (kg) }\end{array}$ & $\begin{array}{l}\text { Estimated } \\
\text { age (mo) }\end{array}$ & $\begin{array}{c}\text { Time } \\
\text { since last } \\
\text { feeding }(\mathrm{h})\end{array}$ & $\begin{array}{c}\text { Estimated } \\
\text { stranding } \\
\text { age }(\mathrm{wk})\end{array}$ & $\begin{array}{l}\text { Time in } \\
\text { captivity } \\
\text { (d) }\end{array}$ & $\begin{array}{l}\text { Time } \\
\text { exposed to } \\
\text { trap (min) }\end{array}$ & $\begin{array}{l}\text { Attempted } \\
\text { to enter } \\
\text { trap? }\end{array}$ & $\begin{array}{c}\text { No. of } \\
\text { times } \\
\text { attempted }\end{array}$ \\
\hline 1 (Eddie) & 13 Jan 99 & $\mathrm{M}$ & 19.1 & 12 & 14 & 13 & 282 & 35 & Yes & 26 \\
\hline 2 (Quinn) & 9 Feb 99 & $\mathrm{M}$ & 10.8 & 6 & 3.5 & 12 & 71 & 112 & No & 0 \\
\hline 3 (Hunter) & 9 Mar 99 & M & 19.2 & 13 & 12 & 1 & 388 & 66 & Yes & 55 \\
\hline 4 (Bud) & 24 Mar 99 & M & 12.0 & 6 & 11 & 5 & 138 & 64 & Yes & 20 \\
\hline 5 (Pippin) & 25 Jun 99 & $\mathrm{~F}$ & 7.0 & 5.5 & 9.5 & 13 & 72 & 37 & No & 0 \\
\hline 6 (Doc) & 25 Jun 99 & $\mathrm{M}$ & 12.0 & 4.5 & 10 & 1 & 127 & 60 & Yes & 5 \\
\hline 7 (Emalin) & 13 Oct 99 & $\mathrm{~F}$ & 11.0 & 6.5 & 12 & 24 & 25 & 60 & No & 0 \\
\hline $8{\text { (Maria })^{a}}^{a}$ & 13 Oct 99 & $\mathrm{~F}$ & 8.3 & 4.5 & 13 & 12 & 53 & 60 & Yes & 3 \\
\hline 9 (Loretta) & 13 Oct 99 & $\mathrm{~F}$ & 18.5 & Adult & 15.5 & Adult & 11 & 60 & No & 0 \\
\hline
\end{tabular}

${ }^{a}$ This sea otter entered the trap completely all 3 times and apparently could not escape on 2 occasions

Table 3. Enhydra lutris. Experiment in which 2 sea otters were exposed to a commercial lobster trap in a controlled setting at the Monterey Bay Aquarium, California. Inner trap funnel had a 6.0 inch $(15.2 \mathrm{~cm})$ diameter opening into the first chamber and 5.5 inch $(14.0 \mathrm{~cm})$ diameter opening into the inner chamber. F: female, M: male

\begin{tabular}{|c|c|c|c|c|c|c|c|c|c|c|}
\hline $\begin{array}{l}\text { Otter no. } \\
\text { (name) }\end{array}$ & $\begin{array}{l}\text { Date } \\
\text { tested }\end{array}$ & Sex & $\begin{array}{l}\text { Weight } \\
\text { (kg) }\end{array}$ & $\begin{array}{c}\text { Estimated } \\
\text { age (mo) }\end{array}$ & $\begin{array}{c}\text { Time } \\
\text { since last } \\
\text { feeding }(\mathrm{h})\end{array}$ & $\begin{array}{c}\text { Estimated } \\
\text { stranding } \\
\text { age (wk) }\end{array}$ & $\begin{array}{l}\text { Time in } \\
\text { captivity } \\
\text { (d) }\end{array}$ & $\begin{array}{c}\text { Time } \\
\text { exposed to } \\
\text { trap (min) }\end{array}$ & $\begin{array}{l}\text { Attempted } \\
\text { to enter } \\
\text { trap? }\end{array}$ & $\begin{array}{c}\text { No. of } \\
\text { times } \\
\text { attempted }\end{array}$ \\
\hline $1{\text { (Faye })^{a}}^{a}$ & 25 Jan 00 & F & 10.9 & 5 & 12 & 4 & 122 & 60 & Yes & 11 \\
\hline 2 (Hunter) & 25 Jan 00 & M & 28.1 & 23 & 15 & 1 & 690 & 60 & Yes & 2 \\
\hline
\end{tabular}


ential between the minimum ring diameter and minimum parallel bar distance was 2.0 inch $(5.1 \mathrm{~cm})$, such that a 6.0 inch $(15.2 \mathrm{~cm})$ diameter rigid ring was equivalent to a 4.0 inch $(10.2 \mathrm{~cm})$ parallel bar distance. The relationship between carcass length $(\mathrm{cm})$ and minimum-passable ring diameter (measured in inches; 1 inch $=2.54 \mathrm{~cm}$ ) was:

$$
\text { Diameter }=0.0564 \times \text { Length }-0.147\left(R^{2}=0.780\right)
$$

The relationship between carcass length $(\mathrm{cm})$ and minimum-passable opening height (or inter-bar distance, measured in inches) was:

$$
\text { Height }=0.0515 \times \text { Length }-1.535\left(R^{2}=0.697\right)
$$

Based on these functions, a ring diameter of 6.0 inches $(15.2 \mathrm{~cm})$ would allow the entry of sea otters up to about $110 \mathrm{~cm}$ length (weight: $\sim 18 \mathrm{~kg}$ ), which corresponds to approximately $2 \mathrm{yr}$ of age (Fig. 2). A 6.0 inch $(15.2 \mathrm{~cm})$ ring was typical for finfish traps before November 2001, at which time a 5 inch $(12.7 \mathrm{~cm})$ diameter rigid ring was made mandatory throughout most of the range, largely because of the information gained from exposing captive-held sea otters to finfish traps. Similarly, a 4.0 inches $(10.2 \mathrm{~cm})$ high spacing of the horizontal bars (typical of the rectangular entrance to most Dungeness crab traps) would allow the entry of sea otters up to about $110 \mathrm{~cm}$ length (weight: $18 \mathrm{~kg}$ ).

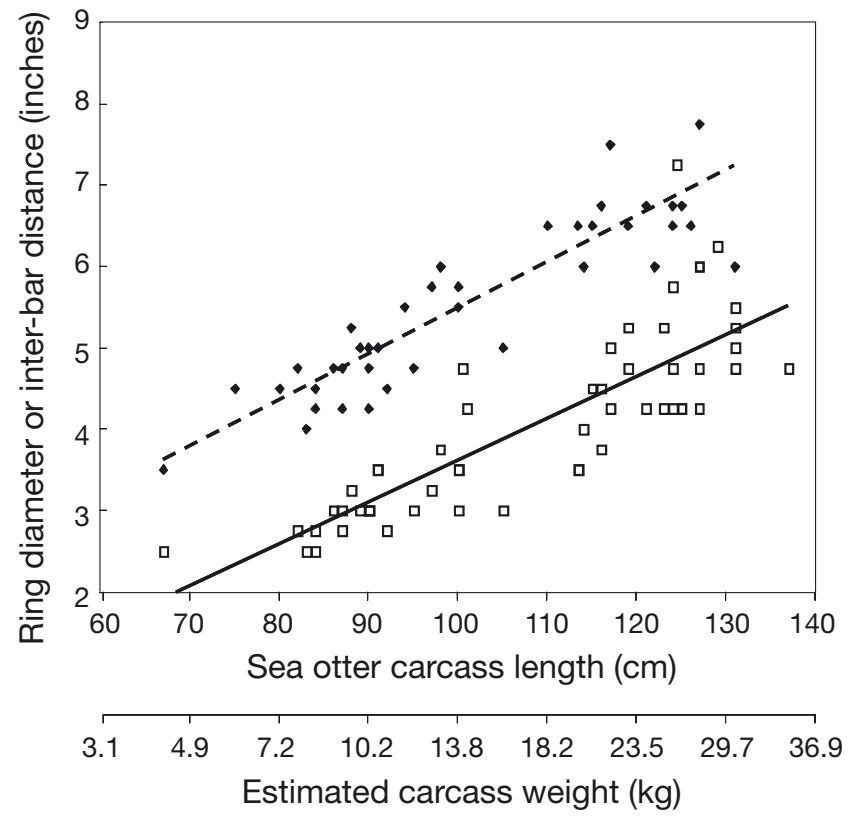

Fig. 2. Enhydra lutris. Minimum ring diameter in inches $(1$ inch $=2.54 \mathrm{~cm})(\checkmark)$ and minimum parallel bar spacing $(\square)$ through which an entire sea otter carcass will fit, plotted against otter size ( $\mathrm{cm}$ or $\mathrm{kg}$ ). Also shown are least-squares linear regression functions fit to the ring-diameter data (dashed line) and parallel bar data (solid line)
Studies with live sea otters

Although we tested fewer living otters, the relationship between sea otter size and the smallest opening through which each animal was able to pass voluntarily (Fig. 3) was similar to that obtained in the carcass analysis. Specifically, the relationship between sea otter mass (kg) and minimum-passable opening height (measured in inches) was:

$$
\text { Height }=0.1426 \times \text { Mass }+1.671\left(R^{2}=0.887\right)
$$

Based on this function, diving sea otters up to about $18 \mathrm{~kg}$ in mass (age $2 \mathrm{yr}$ ) are capable of entering standard Dungeness crab traps with 4.0 inches high by 9.0 inches wide $(10.2$ by $22.9 \mathrm{~cm}$ ) fyke openings. Reducing the height of these openings from 4.0 to 3.0 inches $(10.2$ to $7.6 \mathrm{~cm})$ would limit the size of potentially vulnerable sea otters to approximately $9.0 \mathrm{~kg}$. Animals of this size are typically still dependent pups, an age class that would not likely be diving to depths at which entrapment could occur.

\section{Studies with Dungeness crabs}

Captive studies. We obtained data on exclusion versus opening height from 11 captive-held Dungeness crabs (Table S3 in the supplement at www.int-res.com/ articles/suppl/n013p219_supp.pdf). All crabs tested were able to transit openings $>2.5$ inches $(>6.4 \mathrm{~cm})$ during all trials, whereas none of the crabs tested were able to transit the 2.0 inch $(5.1 \mathrm{~cm})$ opening. Some crabs were able to transit the 2.25 and 2.5 inch $(5.7$ and $6.4 \mathrm{~cm}$, respectively) openings, with the probability of

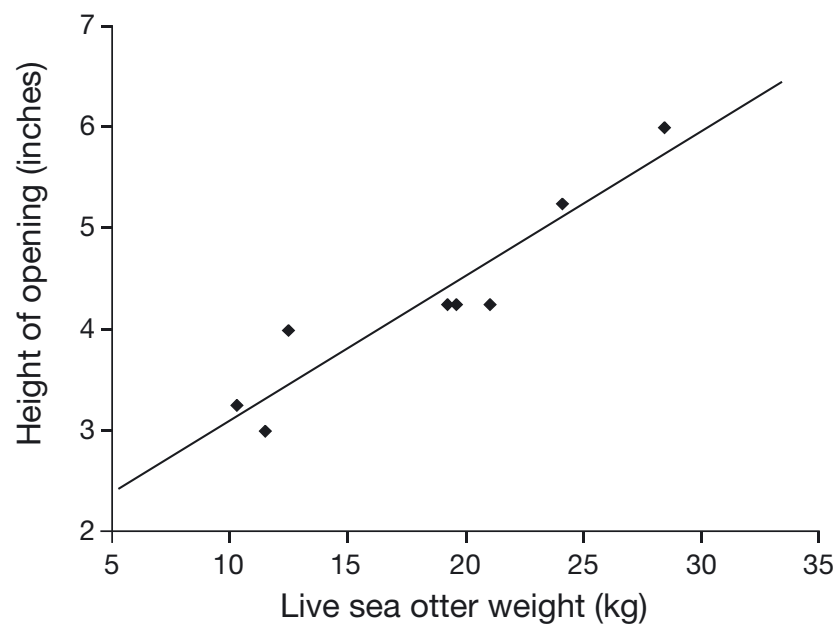

Fig. 3. Enhydra lutris. Smallest rectangular height openings (in inches, 1 inch $=2.54 \mathrm{~cm}$ ) transited by 8 live sea otters (all openings were 9.0 inches [22.9 cm] wide), plotted against otter size $(\mathrm{kg})$. The least-squares linear regression function fit to these data is shown (solid line) 
exclusion being an increasing function of crab size (Fig. 4). The probability of exclusion with a 2.25 inch $(5.7 \mathrm{~cm})$ opening was $<50 \%$ for crabs with a carapace width of $16.2 \mathrm{~cm}$ or less, while the probability of exclusion with a 2.5 inch $(6.4 \mathrm{~cm})$ opening was $<50 \%$ for crabs with a carapace width of up to $18.0 \mathrm{~cm}$. (The minimum legal commercial carapace width is 6.25 inches or $15.9 \mathrm{~cm}$ for the California fishery.) Thus, in a captive setting and when induced with bait, most Dungeness crabs could pass through smaller openings than are used on existing traps. However, these results do not address the question of whether crabs would transit smaller openings in the open ocean and whether they would do so at rates comparable to existing traps.

Open-ocean Dungeness-crab trapping experiments. Over 6000 Dungeness crabs were caught and measured off Half Moon Bay, California, between spring 2004 and fall 2005. Neither the average size (Fig. 5A) nor the CPUE (Fig. 5B) of crabs differed significantly among traps with fyke openings $\geq 2.75$ inches $(7.0 \mathrm{~cm})$, whereas both of these statistics declined significantly with fyke openings $\leq 2.5$ inches $(\leq 6.4 \mathrm{~cm}$ ) (ANOVA for carapace size: $F_{6,308}=35.12, \mathrm{p}<0.0001$; ANOVA for CPUE: $\left.F_{6,308}=17.45, \mathrm{p}<0.0001\right)$. ANOVA assumptions of normally distributed residuals were met for comparisons of crab size (Lilliefors test: $K=0.034, \mathrm{p}=0.5$ ) and CPUE (Lilliefors test: $K=0.042, \mathrm{p}=0.197$ ). The variance of residuals among groups was found to be unequal for both tests (Levene's test: $L_{6,308}=5.35$ and $L_{6,308}=9.44$ for crab size contrast and CPUE contrast, respectively; $\mathrm{p}<0.05$ in both cases); however, graphical examination of residuals suggested that the viola-

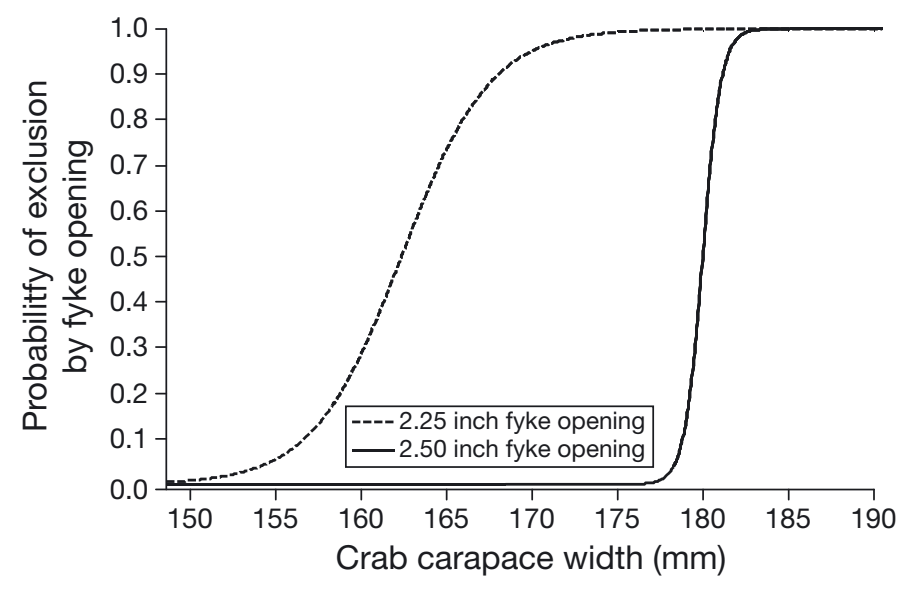

Fig. 4. Cancer magister. Probability of exclusion of Dungeness crabs by fyke openings of 2.25 inches $(5.7 \mathrm{~cm}$ ) (dashed line) and 2.5 inches $(6.4 \mathrm{~cm}$ ) (solid line) as a function of crab carapace width. Lines represent probabilities (p) estimated from logit functions fit to experimental data (Table S3 in the supplement at www.int-res.com/articles/suppl/n013p219_ supp.pdf). Not shown are exclusion probabilities for fyke openings $>2.5$ inches $(>6.4 \mathrm{~cm})(\mathrm{p}=0$ for all sizes measured) and $<2.25$ inches $(<5.7 \mathrm{~cm}) \quad(\mathrm{p}=1$ for all sizes measured)
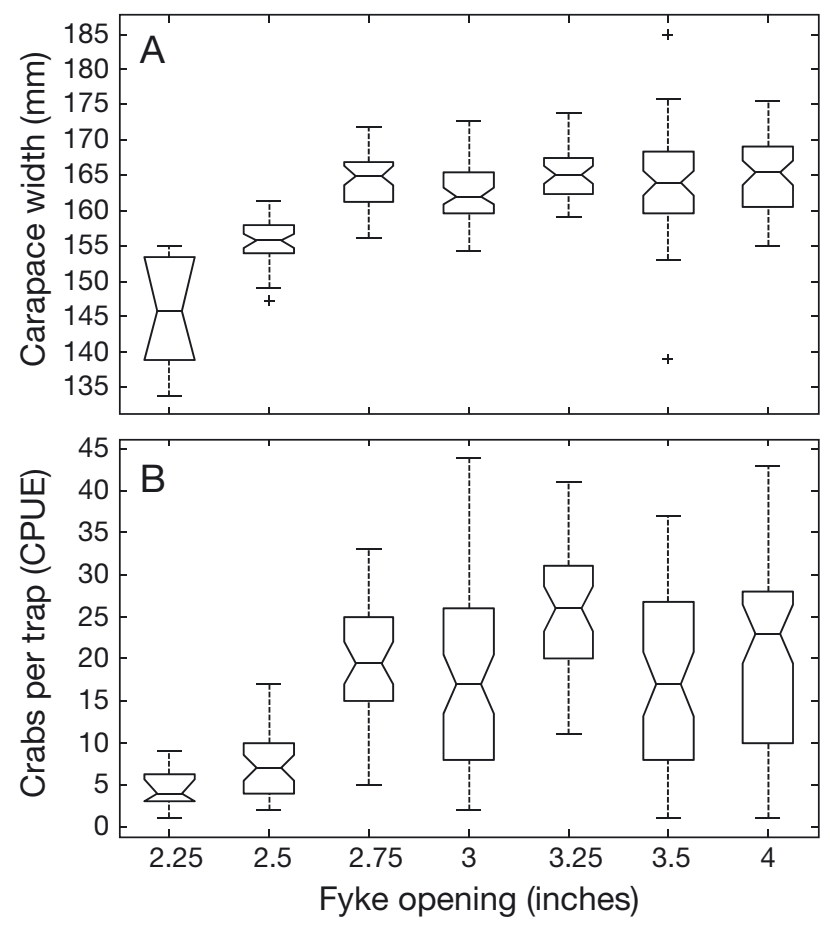

Fig. 5. Cancer magister. Box-plots for Dungeness-crab fishing experiments over 3 seasons. (A) Mean carapace width of crabs caught in traps with fyke openings (in inches: 1 inch $=2.54 \mathrm{~cm}$ ) of various heights. Crab size did not differ significantly for fyke openings of 2.75 to 4.0 inches ( 7.0 to $10.2 \mathrm{~cm}$ ), but dropped significantly (compared to the 4 inch $[10.2 \mathrm{~cm}]$ control treatment) for fyke openings $<2.75$ inches $(<7.0 \mathrm{~cm})$. (B) Catch-per-uniteffort (CPUE) for traps with fyke openings of various heights. CPUE did not differ significantly for fyke openings of 2.75 to 4.0 inches $(7.0$ to $10.2 \mathrm{~cm}$ ), but was reduced significantly (compared to the 4.0 inch $[10.2 \mathrm{~cm}]$ opening in the control treatment) for fyke openings $<2.75$ inches $(<7.0 \mathrm{~cm})$

tions of homoscedasticity were not extreme and thus results from the ANOVA were considered reliable. The mean \pm SD carapace width of crabs caught in traps with fyke openings $\geq 2.75$ inches was $164.1 \mathrm{~mm}( \pm 5.12)$, as compared to $153.8 \mathrm{~cm}( \pm 5.87)$ for traps with fyke openings $\leq 2.5$ inches $(6.4 \mathrm{~cm})$. Likewise, the mean CPUE for traps with fyke openings $\geq 2.75$ inches $(7 \mathrm{~cm}$ ) was $19.8 \pm 10.15$ crabs trap $^{-1}$, compared to $6.8 \pm 3.95$ crabs trap ${ }^{-1}$ for traps with fyke openings $\leq 2.5$ inches $(6.4 \mathrm{~cm})$. These results indicate that reducing the fykeopening height from the current 4.0 inches $(10.2 \mathrm{~cm})$ to 3.0 inches $(7.6 \mathrm{~cm})$ would not significantly affect the number or size of harvested crabs, but would exclude all or most diving sea otters.

\section{Estimating observer effort}

The number of trap pulls that an observer program would have to monitor to have a sufficiently high prob- 


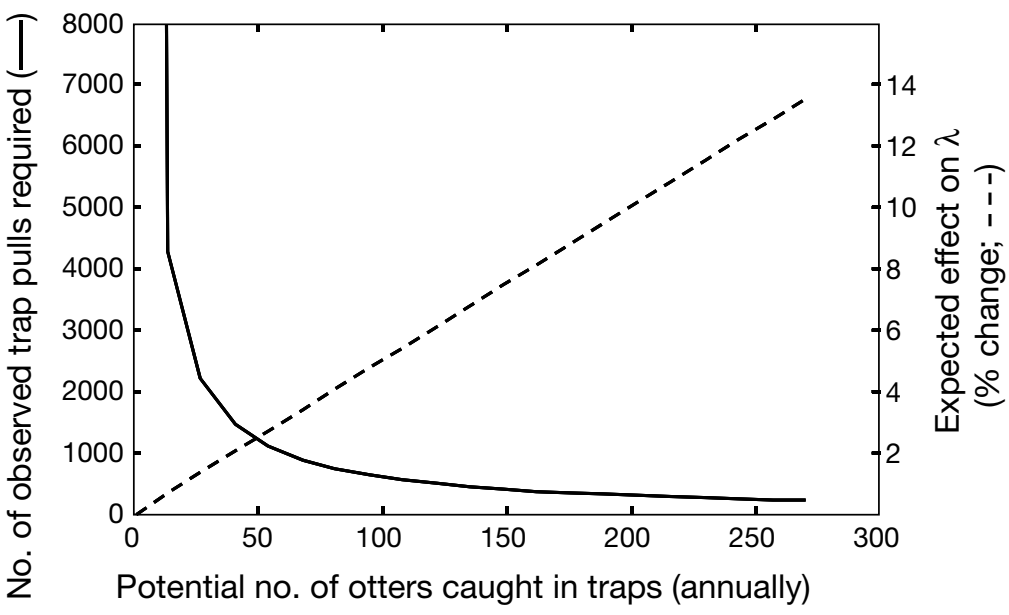

Fig. 6. Enhydra lutris. Effect of various levels of trap mortality on required observing effort and population dynamics. The number of trap pulls that would have to be monitored to have a $95 \%$ chance of detecting $\geq 1$ deaths is shown as a function of actual number of deaths per year (solid line, left vertical axis). Also shown is the percent increase in population growth $(\lambda)$ that would occur if a given level of mortality were prevented (dashed line, right vertical axis)

ability of detecting sea otter mortality (were it occurring) is a decreasing and non-linear function of the actual mortality level (Fig. 6). If the level of mortality is small (1 to 20 deaths $\mathrm{yr}^{-1}$ ), then the probability of detecting it is extremely low unless $>5000$ trap pulls were monitored. Even a mortality rate of 50 sea otters $\mathrm{yr}^{-1}$ in crab traps - a level of mortality sufficient to cause a $2.5 \%$ change in the rate of population growth if these were all juveniles and subadults-would require the monitoring of 1200 trap pulls $\mathrm{yr}^{-1}$ to assure a $95 \%$ or greater probability of observing at least 1 death.

\section{DISCUSSION}

Our results show conclusively that sea otters are physically capable of entering traps with circular openings $>5$ inches $(>12.7 \mathrm{~cm})$ in diameter or rectangular openings $>3$ inches $(>7.6 \mathrm{~cm})$ high, and that captive animals willingly pass through the fyke openings of Dungeness crab pots as long as they can physically squeeze their bodies through the opening. Based on this evidence, we conclude that gear types currently in use in the live-finfish trap fishery south of Point Arguello, the Dungeness crab fishery, and the spiny lobster fishery all pose risks to diving and foraging sea otters. The 5.0 inch $(12.7 \mathrm{~cm})$ diameter circular fyke opening of finfish traps, now mandated within most of the sea otter range, should largely mitigate sea otter drownings. However, the 5.5 to 6.0 inch (14.0 to $15.2 \mathrm{~cm}$ ) diameter circular finfish fyke openings and the typical 4 inch $(10.2 \mathrm{~cm})$ high opening in Dungeness crab pots would allow the passage of sea otters up to about $2 \mathrm{yr}$ of age. Moreover, even older sea otters could enter the fyke openings of the typical spiny lobster pots and finfish traps with larger openings.

Although sea otters can easily enter many traps and pots, whether they can exit as easily once inside is less clear. Dungeness crab pots have small fyke openings and thus it may be difficult for entrapped otters to find their way back through. Entrance openings for fish and lobster traps are somewhat larger so that otters might be able to escape from these devices more easily. However, the opening in the trap that drowned 2 otters near Monterey in 1987 was relatively large (10.0 inches or $25.4 \mathrm{~cm}$ in diameter; Table 1; Fig. S1 in the supplement) - an opening that could be easily transited by even the largest sea otter-yet neither animal escaped. Moreover, the captive sea otter that entered the fish trap in the Monterey Bay Aquarium trap trials, while not left in the trap for extended periods, appeared to panic, and flailed aimlessly before researchers raised the trap out of the water and released the animal. Difficulties probably occur because fyke openings extend into the interior of a trap, away from the perimeter where an entrapped animal would likely focus its attempt at escape. Some lobster traps and most Dungeness crab traps have 1-way 'triggers' in the entrance fykes that would effectively eliminate the chance of escape by an entrapped otter.

We also do not know if wild otters would be more or less likely than captives to enter traps. Wild otters might be less prone than captives to approach foreign objects. Conversely, wild otters in central California appear to be strongly food-limited (Tinker et al. 2008b), and these animals might be more motivated by hunger than their captive counterparts, which are well fed. By this same logic, sea otters at San Nicolas Island might be less inclined to enter lobster pots because food is abundant there (Bentall 2005, Tinker et al. 2008b). The resolution of these questions awaits further data and analysis.

To what degree has bycatch contributed to the overall mortality in the California sea otter population? A concerted effort is being made in central California to determine the magnitude and causes of death in sea otters. However, about half of the total deaths are unaccounted for (Estes et al. 2003, Gerber et al. 2004), and drowned sea otters sink with a low probability that their carcasses will be recovered, especially when 
released in water deeper than $\sim 25 \mathrm{~m}$ (Fig. 1). Hence, there is at least the possibility that some of these unaccounted for animals are lost to bycatch in traps. In addition, the carcasses of such bycatch victims would be in an advanced state of decomposition, thereby making the cause of death difficult or impossible to ascertain.

Bycatch mortality might also be determined through an observer program. However, current levels of surveillance are insufficient to provide useful information. Our analyses caution against the haphazard implementation of such efforts because even concerted observer efforts have a relatively high likelihood of failure, given the high number of pulls required to detect a bycatch problem (Fig. 6). An inadequate observer program could easily lead to a false-negative result, which is unarguably worse than no information at all. Further analyses are needed to assure that both the design and effort of any future observer program would characterize the magnitude of bycatch with a high level of confidence.

A more proactive and positive approach to reducing potential bycatch of California sea otters is through gear modification. We demonstrated that narrowing Dungeness-crab trap openings by 1.0 inch $(2.5 \mathrm{~cm})$ would have little detrimental effect on crab catch but would essentially eliminate the risk of sea otter entrapment. Similarly, 'otter guards' deployed on fyke nets in Europe have been shown to be effective at reducing bycatch of river otters (Poole et al. 2007). Bycatch mitigation through entry-port modifications may prove more problematic for the finfish and lobster fisheries, as the typical outer fyke-opening size of pots and traps used in these fisheries are much larger than they are in the Dungeness crab fishery. Restricting the openings of these traps to prohibit the entry of sea otters could thus render them ineffective.

If bycatch in crab, lobster, and finfish traps with unregulated fyke openings is indeed causing meaningful levels of mortality in the California sea otter population, these effects are probably greater at the northern and southern ends of the population's present range. Although the current mainland range of the California sea otter has only a minimal overlap with the lobster and finfish trap fisheries in the area near Point Conception, more intensive lobster and finfish fisheries occur south of Point Conception, especially around California's Channel Islands. Because of the relatively large fyke openings of traps used in these fisheries, any southward expansion of the California sea otter's range will place an increasing number of otters at risk. This may already be a significant problem at San Nicolas Island, perhaps to some degree explaining the slower-than-expected growth of the small, translocated sea otter population there. The southern end of the Dungeness crab fishery overlaps slightly with the current northern end of the range of the California sea otter. This is an intensive fishery, involving numerous vessels and thousands of pot sets in water depths that are accessible to foraging sea otters, which will dive to depths of up to $100 \mathrm{~m}$ (Bodkin et al. 2004, Tinker et al. 2007). By virtue of its sheer magnitude, this fishery may constitute a significant threat to the northward range expansion of the California sea otter.

The approach we have taken to better understanding and mitigating bycatch in California sea otters might be applied to other species or areas where direct estimates of bycatch mortality are unavailable or impossible to obtain. As with other studies that have had to rely on indirect or incomplete information to evaluate bycatch impacts (Arnold et al. 2006, Slooten 2007, Veran et al. 2007, Moore \& Read 2008), our results demonstrate that the lack of direct estimates of bycatch rates does not justify ignoring a potential problem that could thwart the recovery of a threatened species.

Acknowledgements. Many people helped with various parts of the work described in this article; we thank them all. From the US Geological Survey's Biological Resources Division: M. Kenner, A. Kage, and C. Alfano. From the California Department of Fish and Game: F. Wilhelm, K. Starzel, R. C. Mitchell, N. Moore, J. Geibel, M. Reed, E. Berberich, J. Hardwick, and A. Fisher. From the Monterey Bay Aquarium: J. Coffey, M. Jeffries, G. Krilanovich, L. McKinnon, A. Pereyra, J. Stewart, K. Mayer, J. Hymer, and M. Murray. From the University of California, Santa Cruz: T. Fink. Unaffiliated volunteer: A. Brody. Part of the work conducted by the California Department of Fish and Game on this project was funded by an Endangered Species Act Section 6 grant from the US Fish and Wildlife Service. Activities with live sea otters and traps were conducted under Federal Fish and Wildlife Permit MA843203-0. Any use of trade, product, or firm names in this publication is for descriptive purposes only and does not imply endorsement by the US government. All the research conducted in our experiments was in accordance with institutional and national guidelines concerning the use of animals in research.

\section{LITERATURE CITED}

Alverson DL, Freeberg MH, Murawski SA, Pope JG (1994) A global assessment of fisheries bycatch discards. FAO Fish Tech Pap 339. FAO, Rome

Arnold JM, Brault S, Croxall JP (2006) Albatross populations in peril: a population trajectory for black-browed albatrosses at South Georgia. Ecol Appl 16:419-432

Bentall G (2005) Morphological and behavioral correlates of population status in the southern sea otter, Enhydra lutris nereis: a comparative study between central California and San Nicolas Island. MA thesis, University of California, Santa Cruz, CA

Bodkin JL, Esslinger GG, Monson DH (2004) Foraging depths of sea otters and implications to coastal marine communities. Mar Mamm Sci 20:305-321 
Campbell R, Holley D, Christianopoulos D, Caputi N, Gales N (2008) Mitigation of incidental mortality of Australian sea lions in the west coast rock lobster fishery. Endang Species Res 5:345-358

Crowder LB, Hazen EL, Avissar N, Bjorkland R, Latanich K, Ogburn MB (2008) The impacts of fisheries on marine ecosystems and the transition to ecosystem-based management. Annu Rev Ecol Syst 39:259-278

Estes JA (1990) Growth and equilibrium in sea otter populations. J Anim Ecol 59:385-400

Estes JA, Duggins DO, Rathbun G (1989) The ecology of extinctions in kelp forest communities. Conserv Biol 3:252-264

Estes JA, Hatfield BB, Ralls K, Ames J (2003) Causes of mortality in California sea otters during periods of population growth and decline. Mar Mamm Sci 19:198-216

Gerber LR, Tinker T, Doak D, Estes J (2004) Mortality sensitivity in life-stage simulation analysis: a case study of southern sea otters. Ecol Appl 14:1554-1565

Hall MA (1996) On bycatches. Rev Fish Biol Fish 6:319-352

Hart KM, Mooreside P, Crowder L (2006) Interpreting the spatio-temporal patterns of sea turtle strandings: going with the flow. Biol Conserv 129:283-290

Hatfield BB (2005) The translocation of sea otters to San Nicolas Island: an update. In: Garcelon DK, Schwemm CA (eds) Proc 6th California Islands Symp. National Park Service Tech Publ CHIS-05-01. Institute for Wildlife Studies, Arcata, CA, p 473-475

Jessup DA, Miller MA, Kreuder-Johnson C, Conrad PA, Tinker MT, Estes J, Mazet JAK (2007) Sea otters in a dirty ocean. J Am Vet Med Assoc 231:1648-1652

Kenyon KW (1969) The sea otter in the eastern Pacific Ocean. North Am Fauna 68:1-369

Kreuder C, Miller MA, Jessup DA, Lowenstine LJ and others (2003) Patterns of mortality in southern sea otters (Enhydra lutris nereis) from 1998-2001. J Wildl Dis 39:495-509

Laidre KL, Estes JA, Tinker MT, Bodkin J, Monson D, Schneider K (2006) Patterns of growth and body condition in sea otters from the Aleutian archipelago before and after the recent population decline. J Anim Ecol 75:978-989

Lewison RL, Crowder LB, Read AJ, Freeman SA (2004) Understanding impact of fisheries bycatch on marine megafauna. Trends Ecol Evol 19:598-604

Melvin EF, Parrish JK (eds) (2001) Seabird bycatch: trends, roadblocks, and solutions. Publ. no. AK-SG-01-01. University of Alaska Sea Grant, Fairbanks, AK

Miller MA, Gardner IA, Kreuder C, Paradies DM and others (2002) Coastal freshwater runoff is a factor for Toxoplasma gondii infection of southern sea otters (Enhydra lutris nereis). Int J Parasitol 32:997-1006

Moore JE, Read AJ (2008) A Bayesian uncertainty analysis of cetacean demography and bycatch mortality using age-atdeath data. Ecol Appl 18:1914-1931

Newby TC (1975) Record of a sea otter, Enhydra lutris, 65 miles from shore. Murrelet 56:13

Peckham SH, Diaz DM, Walli A, Ruiz G, Crowder LB, Nichols WJ (2007) Small-scale fisheries bycatch jeopardizes endangered Pacific loggerhead turtles. PLoS ONE 2(10):e1041

Perez MA (2003) Compilation of marine mammal incidental take data from the domestic and joint venture groundfisheries in the US EEZ of the North Pacific, 1989-2001. NOAA Tech Memo NMFS-AFSC-138. US Department of Commerce, Alaska Fisheries Science Center, Seattle, WA

Poole WR, Rogan G, Mullen A (2007) Investigation into the impact of fyke nets on otter populations in Ireland. Irish Wildlife Manual, No. 27. National Parks and Wildlife Service, Department of Environment, Heritage and Local Government, Dublin

Ralls K, DeMaster D, Estes JA (1996) Developing delisting criteria for threatened and endangered species under the Endangered Species Act. Conserv Biol 10:1528-1537

Read AJ, Drinker P, Northridge S (2006) Bycatch of marine mammals in US and global fisheries. Conserv Biol 20: $163-169$

Slooten E (2007) Conservation management in the face of uncertainty: effectiveness of four options for managing Hector's dolphin bycatch. Endang Species Res 3:169-179

Thomas NJ, Cole RA (1996) The risk of disease and threats to the wild population. Endang Species Update 13(Spec Issue):23-27

Thomas NJ, Dubey JP, Lindsay DS, Cole RA, Meteyer CU (2007) Protozoal meningoencephalitis in sea otters (Enhydra lutris): a histopathalogical and immunohistochemical study of naturally occurring cases. J Comp Pathol 137: 102-121

Tinker MT, Doak DF, Estes JA, Hatfield BB, Staedler MM, Bodkin JL (2006) Incorporating diverse data and realistic complexity into demographic estimation procedures for sea otters. Ecol Appl 16:2293-2312

Tinker MT, Costa DP, Estes JA, Wieringa N (2007) Individual dietary specialization and dive behavior in the California sea otter: using archival time-depth data to detect alternative foraging strategies. Deep-Sea Res II 54: 330-342

Tinker MT, Doak DF, Estes JA (2008a) Using demography and movement behavior to predict range expansion of the southern sea otter. Ecol Appl 18:1781-1794

Tinker MT, Bentall G, Estes JA (2008b) Food limitation leads to behavioral diversification and dietary specialization in sea otters. Proc Natl Acad Sci USA 105:560-565

Veran S, Gimenez O, Flint E, Kendall WL, Doherty PF, Lebreton JD (2007) Quantifying the impact of longline fisheries on adult survival in the black-footed albatross. J Appl Ecol 44:942-952

Wendell FE, Hardy RA, Ames JA (1986) An assessment of the accidental take of sea otters, Enhydra lutris, in gill and trammel nets. Mar Resour Tech Rep 54. Calififornia Department of Fish and Game, Sacramento, CA

Zydelis R, Bellebaum J, Osterblom H, Vetemaa M and others (2009) Bycatch in gillnet fisheries - an overlooked threat to waterbird populations. Biol Conserv 142:1269-1281 